\title{
Enhanced Tonic Inhibition Influences the Hypnotic and Amnestic Actions of the Intravenous Anesthetics Etomidate and Propofol
}

\author{
Karla Kretschmannova, ${ }^{1 \star}$ Rochelle M. Hines, ${ }^{1 \star}$ Raquel Revilla-Sanchez, ${ }^{1}$ Miho Terunuma, ${ }^{1}$ Verena Tretter, ${ }^{3}$ \\ Rachel Jurd, ${ }^{1}$ Max B. Kelz, ${ }^{2}$ Stephen J. Moss, ${ }^{1,4}$ and Paul A. Davies ${ }^{1}$ \\ ${ }^{1}$ Department of Neuroscience, Tufts University School of Medicine, Boston, Massachusetts 02111, ${ }^{2}$ Department of Anesthesiology \& Critical Care, University of \\ Pennsylvania, Philadelphia, Pennsylvania 19104, ${ }^{3}$ Department of Anaesthesia, General Intensive Care and Pain Management, Medizinische Universität Wien, 1090 \\ Vienna, Austria, and ${ }^{4}$ Department of Neuroscience, Physiology \& Pharmacology, University College, London, WC1E 6BT, United Kingdom
}

Intravenous anesthetics exert a component of their actions via potentiating inhibitory neurotransmission mediated by $\gamma$-aminobutyric type-A receptors $\left(\mathrm{GABA}_{\mathrm{A}} \mathrm{Rs}\right)$. Phasic and tonic inhibition is mediated by distinct populations of $\mathrm{GABA}_{\mathrm{A}} \mathrm{Rs}$, with the majority of phasic inhibition by subtypes composed of $\alpha 1-3 \beta \gamma 2$ subunits, whereas tonic inhibition is dependent on subtypes assembled from $\alpha 4-6 \beta \delta$ subunits. To explore the contribution that these distinct forms of inhibition play in mediating intravenous anesthesia, we have used mice in which tyrosine residues $365 / 7$ within the $\gamma 2$ subunit are mutated to phenyalanines (Y365/7F). Here we demonstrate that this mutation leads to increased accumulation of the $\alpha 4$ subunit containing $\mathrm{GABA}_{\mathrm{A}} \mathrm{Rs}$ in the thalamus and dentate gyrus of female Y365/7F but not male Y365/7F mice. Y365/7F mice exhibited a gender-specific enhancement of tonic inhibition in the dentate gyrus that was more sensitive to modulation by the anesthetic etomidate, together with a deficit in long-term potentiation. Consistent with this, female Y365/7F, but not male Y365/7F, mice exhibited a dramatic increase in the duration of etomidate- and propofol-mediated hypnosis. Moreover, the amnestic actions of etomidate were selectively potentiated in female Y365/7F mice. Collectively, these observations suggest that potentiation of tonic inhibition mediated by $\alpha 4$ subunit containing GABA $\mathrm{A}_{\mathrm{A}}$ contributes to the hypnotic and amnestic actions of the intravenous anesthetics, etomidate and propofol.

\section{Introduction}

Despite their widespread use to cause a reversible loss of consciousness, the exact molecular mechanisms and brain networks affected by general anesthetics remain unknown (Franks, 2008; Brown et al., 2011). Intravenous anesthetics are known to act via $\gamma$-aminobutyric acid type $\mathrm{A}$ receptors $\left(\mathrm{GABA}_{\mathrm{A}} \mathrm{Rs}\right)$, which are ligand-gated ion channels assembled from multiple subunit classes. Subtypes assembled from $\alpha 1-3 \beta \gamma 2$ subunits are largely responsible for phasic inhibition, whereas those containing $\alpha 4-6 \beta \delta$ subunits mediate tonic inhibition (Olsen and Sieghart, 2008).

Received Nov. 26, 2012; revised March 14, 2013; accepted March 15, 2013.

Author contributions: K.K., R.M.H., R.R.-S., M.T., V.T., R.J., M.B.K., S.J.M., and P.A.D. designed research; K.K., R.M.H., R.R.-S., M.T., V.T., R.J., and M.B.K. performed research; K.K., R.M.H., R.R.-S., M.T., M.B.K., S.J.M., and P.A.D. analyzed data; K.K., R.M.H., M.B.K., S.J.M., and P.A.D. wrote the paper.

P.A.D. was supported by NIH NIAAA Grant AA017938 and NIH NIMH Grant MH097446. S.J.M. was supported by NIHNINDS Grants NS051195, NS056359, and NS081735, NIH NIMH Grant MH097446, CURE, and the Simons Foundation. S.J.M. serves as a consultant for SAGE therapeutics and Astrazeneca, relationships that are regulated by Tufts University and do not impact on this study. M.B.K. was supported by NIH NIGMS Grant GM088156. M.T. received a National Scientist Development Award from the American Heart Association. R.M.H. was supported by a CIHR postdoctoral fellowship.

The authors declare no competing financial interests.

*K.K. and R.M.H. contributed equally to this work.

Correspondence should be addressed to any of the following: Dr. Max B. Kelz, Department of Anesthesiology \& Critical Care, University of Pennsylvania, Perelman School of Medicine, 3620 Hamilton Walk, 334 John Morgan Building, Philadelphia,PA 19104, E-mail:kelzma@uphs.upenn.edu;Dr.Stephen J.Moss, Department of Neuroscience, Tufts UniversitySchool of Medicine, Harrison Avenue, Boston, MA 02111, E-mail: Stephen.Moss@Tufts.edu; or Dr. Paul A. Davies, Department of Neuroscience, Tufts University School of Medicine, Harrison Avenue, Boston, MA 02111, E-mail: Paul.Davies@Tufts.edu.

DOI:10.1523/JNEUROSCI.5475-12.2013

Copyright $\odot 2013$ the authors $\quad 0270-6474 / 13 / 337264-10 \$ 15.00 / 0$
It has been hypothesized that intravenous anesthetics produce their different endpoints by affecting distinct regions of the brain: loss of consciousness by modulating reticular activating systems, including thalamic-cortical circuits, and amnesia through enhancing inhibition in the hippocampus (Steriade et al., 1993; Alkire and Miller, 2005). Although it is evident that intravenous anesthetics are able to enhance $\mathrm{GABA}_{\mathrm{A}} \mathrm{R}$ subtypes that mediate phasic and tonic inhibition, the relative contribution of these distinct forms of inhibition to the mechanism of anesthesia remains elusive.

Tonic inhibition in the dentate gyrus (DG) of the hippocampus, striatum, outer layer of the cortex, and thalamus is largely mediated by extrasynaptic $\mathrm{GABA}_{\mathrm{A}}$ Rs that contain $\alpha 4 \beta 2 / 3 \delta$ subunits, and activated by ambient concentrations of GABA. The resulting tonic current determines the gain of the neuronal output, thus regulating the excitability of neurons and the activity of neuronal circuits (Semyanov et al., 2004; Belelli et al., 2009). Extrasynaptic $\mathrm{GABA}_{\mathrm{A}}$ Rs containing $\alpha 4$ subunits represent an important pharmacological target. Although they are largely insensitive to benzodiazepines, neurosteroids and intravenous anesthetics have been shown to modulate the tonic current at concentrations that do not modulate inhibitory postsynaptic currents (IPSCs), which are dependent on the activation of synaptic $\mathrm{GABA}_{\mathrm{A}}$ Rs (Bieda and MacIver, 2004; Jia et al., 2008; Belelli et al., 2009; Bieda et al., 2009; Herd et al., 2009).

The efficacy of phasic inhibition is in part determined by regulated $\mathrm{GABA}_{\mathrm{A}} \mathrm{R}$ endocytosis, a critical determinant of which are tyrosine residues 365 and 367 (Y365/7) in the $\gamma 2$ subunit, which 
mediate $\mathrm{GABA}_{\mathrm{A}} \mathrm{R}$ entry into the endocytic pathway (Jacob et al., 2008; Kittler et al., 2008; Jurd and Moss, 2010; Jurd et al., 2010). This is emphasized in male mice in which the respective residues have been mutated to phenylalanines (Y365/7F) as these mice have region-specific increases in the synaptic accumulation of $\mathrm{GABA}_{\mathrm{A}} \mathrm{Rs}$ (Tretter et al., 009). Here we examined the Y365/7F mutation on the efficacy of tonic inhibition and on sensitivity to intravenous anesthetics.

Our results reveal that mutation of Y365/7 has gender-specific effects on tonic inhibition. In female Y365/7F mutant mice, elevated levels of $\alpha 4$ subunit expression are found in the hippocampus and thalamus, but such elevations do not occur in male Y365/7F mice. Consistent with this, tonic inhibition and its potentiation by etomidate, but not phasic inhibition, was enhanced in Y365/7F females compared with wild-type (WT). In parallel, $\mathrm{Y} 365 / 7 \mathrm{~F}^{+/-}$females show enhanced sensitivity to the hypnotic and amnestic effects of etomidate compared with WT females and males. Collectively, our results suggest that the selective potentiation of tonic inhibition is central to the hypnotic and amnestic effects of intravenous anesthetics.

\section{Materials and Methods}

Animals. All procedures were approved by the Institutional Animal Care and Use Committee at Tufts University and the University of Pennsylvania, and were in accordance with National Institutes of Health guidelines. All efforts were made to minimize animal suffering and minimize the number of mice studied in experiments. Mice were housed under controlled conditions with temperatures ranging between $20^{\circ} \mathrm{C}$ and $24^{\circ} \mathrm{C}$, on a 12:12 h light/dark cycle with lights on starting at 7:00 A.M. in an isolated ventilated room with free access to food and water.

Mice homozygous for the Y365/7F mutation die in utero, but heterozygotes survive into adulthood (Tretter et al., 2009). $\mathrm{GABA}_{\mathrm{A}} \gamma 2 \mathrm{Y} 365 / 7 \mathrm{~F}$ heterozygous knock-in $\left(\mathrm{Y}_{365 / 7 \mathrm{~F}^{+/-}}\right)$mice and littermate controls were maintained on a C57BL6/J genetic background and had been backcrossed a minimum of 9 times. The mating scheme used to produce experimental

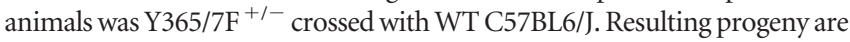
screened by PCR and/or Southern blotting on tail clips taken at 3-4 weeks to determine genotype. Mice were separated at weaning into male and female littermate groups and are housed throughout their lifetime in isolation from other groups in HEPA-filtered ventilated cage racks. We did not observe regular estrus cycling in females from the colony as indicated by noncornified epithelial cells from vaginal smears (Caligioni, 2009; McLean et al., 2012), which has been noted before with isolated females (Whitten, 1957; Marsden and Bronson, 1964, 1965; Champlin, 1971).

Immunohistochemistry. Animals ( $8-13$ weeks old) were anesthetized and intracardially perfused with saline solution followed by $4 \%$ paraformaldehyde. Brains were quickly removed, postfixed overnight, and cryoprotected in $30 \%$ sucrose. Free-floating sections were cut at $40 \mu \mathrm{m}$ using a freezing microtome and stored at $-20^{\circ} \mathrm{C}$ in cryoprotective solution (30\% sucrose, $30 \%$ ethylenglycol, $1 \%$ polyvinylpyrrolidone in PBS) until processing. Sections were washed in PBS and incubated for $10 \mathrm{~min}$ in $0.1 \% \mathrm{H}_{2} \mathrm{O}_{2}$ to block endogenous peroxidase activity. After washing in PBS sections were incubated for $2 \mathrm{~h}$ in blocking solution ( $2 \%$ normal horse serum, $0.5 \% \mathrm{BSA}$, and $0.3 \%$ Triton X-100 in PBS) followed by incubation for $48 \mathrm{~h}$ at $4^{\circ} \mathrm{C}$ in blocking solution containing the primary antibodies against the $\gamma 2$ (Tretter et al., 2009), $\alpha 4$, and $\delta$ subunits (Bencsits et al., 1999).

After rinsing in PBS, sections were incubated in blocking solution containing biotinylated anti-rabbit or guinea pig antibody for $2 \mathrm{~h}$ at room temperature, then rinsed in PBS and incubated for $1 \mathrm{~h}$ in $\mathrm{ABC}$ solution (Vectastain Elite ABC kit, Vectorlabs). After washing, sections were incubated for $10 \mathrm{~min}$ in $\mathrm{DAB}$ (peroxidase substrate) containing nickel chloride as an enhancing reagent. The reaction was terminated by washing twice in water. Sections were mounted onto slides, air-dried, dehydrated through graded alcohols followed by xylenes, and then mounted for viewing. Sections were visualized with an Olympus BX51 microscope (Olympus Optical), and the optical density was obtained using MetaMorph software (Universal Imaging).
Surface biotinylation. Brain slices were chilled to $4^{\circ} \mathrm{C}$ and incubated for $30 \mathrm{~min}$ with $1 \mathrm{mg} / \mathrm{ml} \mathrm{NHS}$-SS-biotin (Pierce). Excess biotin was removed by washing three times in cold artificial CSF and lysed. After correction for protein content, lysates were incubated with streptavidin beads for $12 \mathrm{~h}$ at $4^{\circ} \mathrm{C}$. Bound material was subjected to SDS-PAGE and then immunoblotted with antibodies against the $\gamma 2$ and $\alpha 4$ subunits and visualized by ECL (Pierce). Blots were then quantified using the CCD-based FujiFilm LAS 3000 system.

Hippocampal slice preparation. Brain slices were prepared from 8- to 13-week-old heterozygous $\mathrm{Y} 365 / 7 \mathrm{~F}^{+/-}$mice and control littermates. Mice were anesthetized with isoflurane, decapitated, and brains were rapidly removed and put in an ice-cold cutting solution containing for whole-cell patch-clamp recordings (in mM) as follows: $124 \mathrm{NaCl}, 2.5 \mathrm{KCl}$, $0.5 \mathrm{CaCl}_{2}, 4 \mathrm{MgCl}_{2}, 27 \mathrm{NaHCO}_{3}, 1.25 \mathrm{NaH}_{2} \mathrm{PO}_{4}, 10$ glucose, 1 ascorbic acid, 0.6 sodium pyruvate, and 3 kynurenic acid, and for extracellular field potential recordings (in $\mathrm{mm}$ ) as follows: $85 \mathrm{NaCl}, 75$ sucrose, 2.5 $\mathrm{KCl}, 0.5 \mathrm{CaCl}_{2}, 4 \mathrm{MgCl}_{2}, 24 \mathrm{NaHCO}_{3}, 1.25 \mathrm{NaH}_{2} \mathrm{PO}_{4}, 25$ glucose, 1 ascorbic acid, and 0.6 sodium pyruvate. Coronal $310 \mu \mathrm{m}$ thick (for whole-cell patch-clamp recording) or transversal $400 \mu \mathrm{m}$ thick (for extracellular field potential recording) hippocampal slices were cut with the vibratome VT1000S (Leica Microsystems). Slices were then transferred into incubation chamber filled with prewarmed $\left(32^{\circ} \mathrm{C}-33^{\circ} \mathrm{C}\right)$ oxygenated artificial CSF of the following composition (in $\mathrm{mm}$ ): $124 \mathrm{NaCl}, 2.5 \mathrm{KCl}$, $2 \mathrm{CaCl}_{2}, 1 \mathrm{MgCl}_{2}, 27 \mathrm{NaHCO}_{3}, 1.25 \mathrm{NaH}_{2} \mathrm{PO}_{4}, 10$ glucose, and 3 kynurenic acid; for extracellular field potential recordings, kynurenic acid was omitted and concentration of $\mathrm{NaHCO}_{3}$ was lowered to $24 \mathrm{~mm}$. Slices were allowed to recover for 1.5-2 $\mathrm{h}$ before recording. After recovery, a single slice was transferred to a submerged recording chamber on the stage of an upright microscope (Nikon FN-1) and perfused at rate of $1.5-2 \mathrm{ml} / \mathrm{min}$ with oxygenated $\left(\mathrm{O}_{2} / \mathrm{CO}_{2} 95 / 5 \%\right)$ artificial CSF heated to $32^{\circ} \mathrm{C}-33^{\circ} \mathrm{C}$ by in-line heater (Warner Instruments).

Extracellular field recording. A bipolar concentric platinum-iridium stimulating electrode ( $125 \mu \mathrm{m} / 25 \mu \mathrm{m}$; FHS) was used to stimulate the medial perforant pathway. The field excitatory postsynaptic potentials (fEPSPs) were recorded via a glass micropipette filled with $0.5 \mathrm{M} \mathrm{NaCl}(3-4 \mathrm{M} \Omega$ ) placed in the middle third of the molecular layer. Stimuli (0.1 ms duration) were delivered every $30 \mathrm{~s}$. Stimulus intensity was set to produce $40-50 \%$ of the maximal response, and baseline responses were recorded for $20 \mathrm{~min}$ before inducing LTP. High-frequency stimulation was delivered as four trains of hundred pulses $(100 \mathrm{~Hz}$, for $1 \mathrm{~s})$ with $30 \mathrm{~s}$ of intertrain interval. Data were acquired using Axopatch 200B amplifier (Molecular Devices) and analyzed by pClamp software (Molecular Devices).

Whole-cell patch-clamp recordings. Spontaneous IPSCs (sIPSCs) and tonic currents were recorded from the visually identified somata of granular cells localized in the medial section of suprapyramidal blade of DG. Patch pipettes (5-7 M $\Omega$ ) were pulled from borosilicate glass (World Precision Instruments) and filled with intracellular solution of the composition (in mM) as follows: $130 \mathrm{KCl}, 4 \mathrm{MgCl}_{2}, 0.5 \mathrm{CaCl}_{2}, 10 \mathrm{HEPES}, 5$ EGTA, $2 \mathrm{Mg}$-ATP, 0.3 GTP, pH 7.2. A 5 min period for stabilization after obtaining the whole-cell recording conformation was allowed before currents (holding potential of $-70 \mathrm{mV}$ ) were recorded using an Axopatch 200B amplifier (Molecular Devices), low-pass filtered at $5 \mathrm{kHz}$, digitized at $20 \mathrm{kHz}$ (Digidata 1320A; Molecular Devices), and stored for off-line analysis (using Minianalysis, Synaptosoft).

For tonic current measurements, an all-points histogram was plotted for a $10 \mathrm{~s}$ period before and during drug application, once the response reached a plateau level. Tonic currents were measured as the change in baseline amplitude and normalized to cell capacitance $(\mathrm{pA} / \mathrm{pF})$. For phasic inhibition, amplitude, frequency, and decay time $(\tau)$ of sIPSCs were analyzed using Minianalysis software (Synaptosoft). For decay, at least 30 events without superposition were selected and averaged per cell. Decay was then fitted with biexponential curve, and weighted decay $\left(\tau_{\mathrm{w}}\right)$ was calculated using the equation: $\tau_{\mathrm{w}}=\left(\left(\tau_{1}{ }^{\star} \mathrm{A} 1\right)+\left(\tau_{2}{ }^{*} \mathrm{~A} 2\right)\right) /(\mathrm{A} 1+\mathrm{A} 2)$, where $\mathrm{A} 1$ and $\mathrm{A} 2$ are amplitudes of fast and slow decay components and $\tau_{1}$ and $\tau_{1}$ are their respective decay time constants. Unless otherwise indicated, data were expressed as mean \pm SEM. Statistical significance was determined using $t$ test.

Loss and return of the righting reflex. Anesthetic sensitivity was assayed behaviorally with the loss of righting reflex according to published pro- 
Table 1. Mean ages and weights in $\mathrm{Y} 365 / 7^{+/-}$and WT mice used in righting reflex studies

\begin{tabular}{|c|c|c|c|c|c|c|}
\hline Gender, dose & Heterozygote age (weeks) & WT age (weeks) & $p(t$ test $)$ & Heterozygote weight (g) & WT weight (g) & $p(t$ test $)$ \\
\hline Female, $2.5 \mathrm{mg} / \mathrm{kg}$ etomidate & $15.9 \pm 1.6$ & $14.6 \pm 0.8$ & 0.07 & $20.9 \pm 1.6$ & $20.8 \pm 2.0$ & 0.87 \\
\hline Female, $5 \mathrm{mg} / \mathrm{kg}$ etomidate & $13.8 \pm 4.1$ & $13.9 \pm 3.2$ & 0.98 & $21.5 \pm 1.8$ & $22.5 \pm 1.8$ & 0.32 \\
\hline Female, $10 \mathrm{mg} / \mathrm{kg}$ etomidate & $37.7 \pm 0.7$ & $37.9 \pm 0.3$ & 0.15 & $25.3 \pm 3.4$ & $25.6 \pm 2.4$ & 0.85 \\
\hline Male, $2.5 \mathrm{mg} / \mathrm{kg}$ etomidate & $29.0 \pm 3.0$ & $30.4 \pm 2.8$ & 0.41 & $31.5 \pm 2.4$ & $33.2 \pm 2.6$ & 0.26 \\
\hline Male, $5 \mathrm{mg} / \mathrm{kg}$ etomidate & $25.8 \pm 3.7$ & $26.6 \pm 2.4$ & 0.28 & $30.5 \pm 2.5$ & $31.1 \pm 2.9$ & 0.62 \\
\hline Male, $10 \mathrm{mg} / \mathrm{kg}$ etomidate & $21.6 \pm 4.4$ & $21.9 \pm 5.3$ & 0.92 & $28.8 \pm 2.0$ & $28.8 \pm 2.4$ & 0.99 \\
\hline Female, $20 \mathrm{mg} / \mathrm{kg}$ propofol & $22.2 \pm 3.9$ & $25.7 \pm 2.7$ & 0.05 & $24.0 \pm 4.2$ & $23.2 \pm 1.8$ & 0.60 \\
\hline Male, $20 \mathrm{mg} / \mathrm{kg}$ propofol & $21.9 \pm 1.9$ & $22.7 \pm 1.5$ & 0.40 & $31.9 \pm 2.7$ & $30.7 \pm 0.9$ & 0.27 \\
\hline
\end{tabular}

tocols (Jurd et al., 2003; Sun et al., 2006; Hu et al., 2012). Mice 11-38 weeks of age (Table 1) were only used once in each study and received a single intravenous injection of etomidate 2.5 , 5.0 , or $10.0 \mathrm{mg} / \mathrm{kg}$ or of propofol $20.0 \mathrm{mg} / \mathrm{kg}$ administered in identical volumes of $5 \mathrm{ml} / \mathrm{kg}$ via the tail vein. As loss of righting reflex was instantaneous upon intravenous injection, mice were placed supine into a $200 \mathrm{ml}$ closed cylindrical chamber with $100 \mathrm{ml} / \mathrm{min}$ of fresh air flowing through it immediately after injection. The chamber was placed on a heating pad set to $37^{\circ} \mathrm{C}$ to maintain body temperature during the anesthetic state. The time until return of the righting reflex was recorded by an experimenter blinded to genotype. A total of 21 of 140 were excluded from the study because of failed intravenous injections. Rectal temperatures were measured both before injection and after anesthesia to verify preservation of normothermia. All studies were conducted between ZT6 and ZT8. For analysis of duration of loss of righting reflex, a two-way ANOVA was constructed with main factors of genotype and etomidate dose. Another two-way ANOVA was used to determine the effects of genotype and gender on propofol induced loss of righting. Statistical analysis was conducted using Prism 5.0c (GraphPad Software) with Bonferroni post-testing where appropriate.

Fear conditioning learning. Behavioral studies of Y356/7 $7^{+/-}$mice used WT littermate controls (16 weeks of age), divided into cohorts of four mice per cage. To avoid potential influences of exposure to the opposite sex, males and females were trained and tested on separate days. The experimenter was blind to the drug treatment and genotype of the mice for all studies. Thirty minutes before being placed in the fear conditioning chamber, mice were randomly assigned to receive an intraperitoneal injection $(0.1 \mathrm{ml} / \mathrm{g}$ of body weight) of vehicle (35\% propylene glycol, $10 \%$ dimethyl sulfoxide), or etomidate $(4 \mathrm{mg} / \mathrm{kg})$. The dose of etomidate was based on previous studies demonstrating that $4 \mathrm{mg} / \mathrm{kg}$ results in a state of conscious amnesia with minimal sedation while still resulting in impairment of explicit or episodic memory (Cheng et al., 2006; Martin et al., 2009). During training, individual mice were allowed to explore the novel conditioning context for $180 \mathrm{~s}$ before being exposed to a series of 3 weak $(2 \mathrm{~s}$, $0.5 \mathrm{~mA}$ ) foot shocks, each separated by $57 \mathrm{~s}$ (total training time of $5 \mathrm{~min}$ ). On test day, $24 \mathrm{~h}$ after the conditioning training session, each mouse was assessed for the characteristic freezing response by returning it to the conditioning context for $5 \mathrm{~min}$. Freezing data were analyzed using either two-way ANOVA (average freezing) or two-way repeated-measures ANOVA (training and freezing) with Student-Newman-Keuls where appropriate for multiple-comparison procedures.

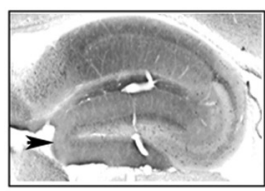

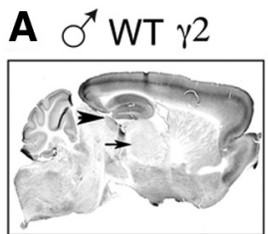
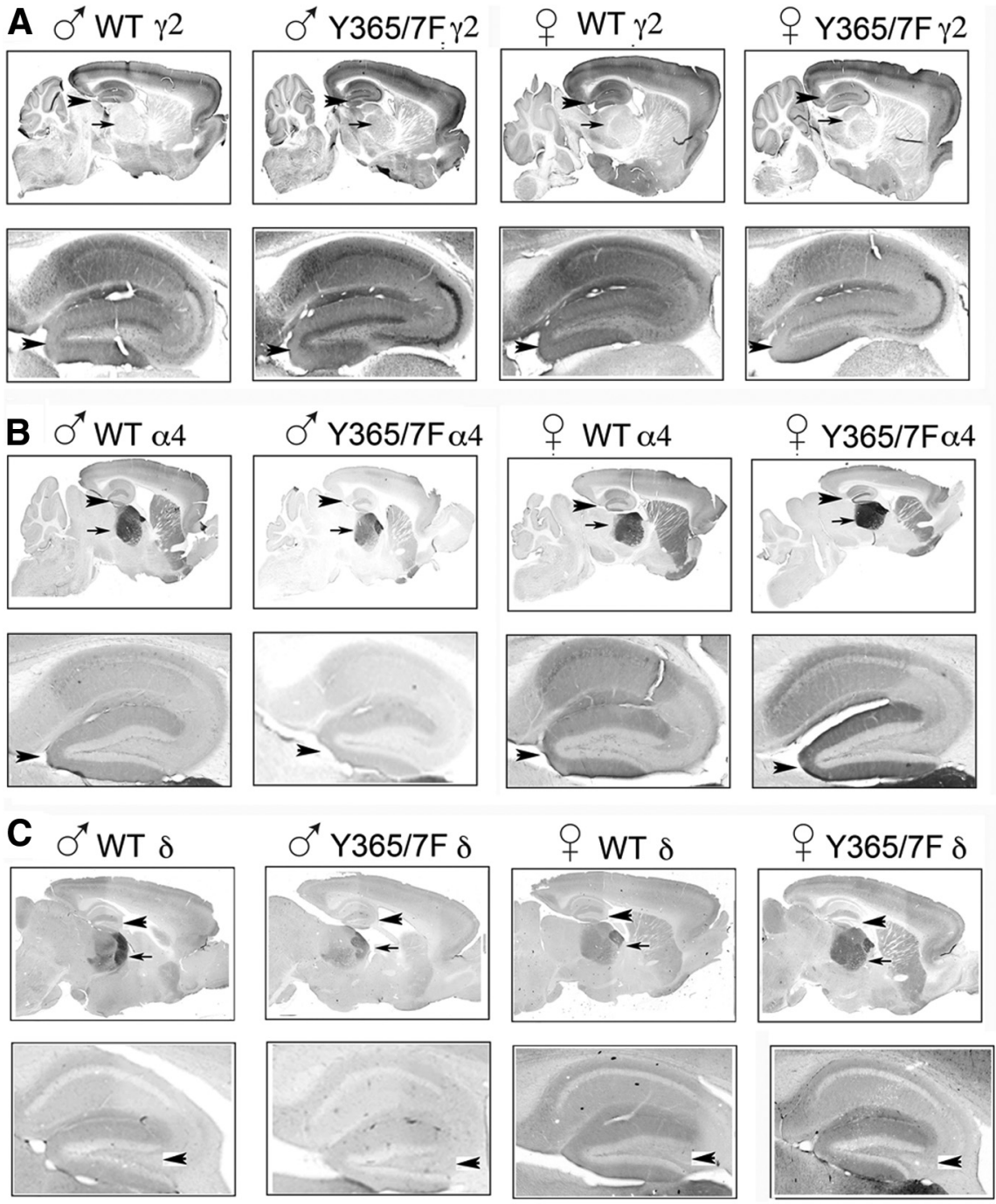

Figure 1. Analysis of $\gamma 2, \alpha 4$, and $\delta$ subunits in the brains of $\mathrm{Y}_{365 / 7 \mathrm{~F}^{+/-}}$mice using immunohistochemistry. The $40 \mu \mathrm{m}$ whole brain sections from male and female WT and $\mathrm{Y} 365 / 7 \mathrm{~F}^{+/-}$mice were stained with antibodies against the $\operatorname{GABA}_{A} \mathrm{R} \gamma 2(\boldsymbol{A})$, $\alpha 4(\boldsymbol{B})$, and $\delta$ subunits $(\boldsymbol{C})$ followed by HRP-conjugated secondary antibodies. The arrowheads indicate the DG, and arrows indicate the thalamus. $A-C$, Bottom, Enlargements of the hippocampus. Arrowheads indicate the DG.

\section{Results}

Mutations of Y365/7F in the $\gamma 2$ subunit have gender-specific effects on the expression levels of $\mathrm{GABA}_{\mathrm{A}} \mathrm{R}$ subtypes that mediate phasic and tonic inhibition

The excitability of neurons is determined by the combined efficacies of phasic and tonic inhibition. To explore how neurons coordinate these processes, we have used mice in which Y365/7 in the $\gamma 2$ subunit have been mutated to phenyalanine residues (Y365/7F) (Kittler et al., 2008; Tretter et al., 2009). Y365/7 is the 
Table 2. Quantifying $\mathrm{GABA}_{\mathrm{A}} \mathrm{R}$ expression levels in the dentate and thalamus of ${\mathrm{Y} 365 / 7 \mathrm{~F}^{+/-}}^{+-}$males and females ${ }^{a}$

\begin{tabular}{|c|c|c|c|c|c|c|}
\hline & Dentate $\gamma 2$ (\% WT) & Dentate $\alpha 4$ (\% WT) & Dentate $\delta(\% \mathrm{WT})$ & Thalamus $\gamma 2$ (\% WT) & Thalamus $\alpha 4$ (\% WT) & Thalamus $\delta(\%$ WT) \\
\hline Male heterozygotes & $144.3 \pm 11.2^{*}$ & $55.4 \pm 6.4^{*}$ & $72.9 \pm 9.2^{*}$ & $162.8 \pm 19.2^{*}$ & $62.5 \pm 9.2^{*}$ & $59.4 \pm 8.9^{*}$ \\
\hline Female heterozygotes & $65.5 \pm 7.4^{*}$ & $164.8 \pm 11.2^{*}$ & $146.7 \pm 13.2^{*}$ & $42.2 \pm 5.2^{*}$ & $195.4 \pm 19.2^{*}$ & $153.3 \pm 11.2^{*}$ \\
\hline
\end{tabular}

${ }^{a}$ pptical density measurements of DAB reaction product were acquired by stereology and quantified using MetaMorph after subtraction of background staining in parallel sections without primary antibody. Data were normalized to levels seen in WT (control $=100 \%$ ) for each sex.

*Significantly different from control $(p<0.01) ; n=5-7$.

principal determinant of the membrane trafficking of $\mathrm{GABA}_{\mathrm{A}} \mathrm{Rs}$ subtypes that mediate phasic inhibition. In males harboring the Y365/7F mutation, increased plasma membrane accumulation of $\gamma 2$ subunit containing $\mathrm{GABA}_{\mathrm{A}}$ Rs was evident and correlated with increased phasic inhibition in the CA3 region of the hippocampus (Tretter et al., 2009).

To assess whether this mutation impacts tonic inhibition, we compared the expression levels of subtypes containing $\alpha 4$ and $\gamma 2$ subunits in the hippocampus of Y365/7F mice using immunohistochemistry with previously characterized antibodies against these subunits and HRP-conjugated secondary antibodies was performed (Chandra et al., 2006; Tretter et al., 2009). HRPreaction product was then quantified in multiple areas of interest of the hippocampus using stereology. The $\alpha 4$ subunit was chosen for study because it is accepted to be a component of $\mathrm{GABA}_{\mathrm{A}} \mathrm{R}$ subtypes that mediate tonic inhibition in the DG, thalamus, and neocortex (Chandra et al., 2006). Our studies were limited to heterozygotes because mice homozygous for the Y365/7F mutation die in utero (Tretter et al., 2009). Consistent with published studies, increases in $\gamma 2$ expression were apparent in the hippocampus of $\mathrm{Y} 365 / 7 \mathrm{~F}^{+/-}$males, including the CA3 (Fig. $1 A$ ) (Tretter et al., 2009). Quantifying HRP reaction product in the DG of $Y 365 / 7 \mathrm{~F}^{+/-}$mice revealed $\gamma 2$ expression levels were increased compared with control WT males (Fig. 1A; Table 2; $p=$ $0.007 ; n=5$ ). In contrast, $\alpha 4$ subunit levels were reduced (Fig. $1 A$; Table $2 ; p=0.008 ; n=5$ ). Consistent with these deficits, the level of $\delta$ subunit expression that coassembles with the $\alpha 4$ subunit was reduced in $\mathrm{Y} 365 / 7 \mathrm{~F}^{+/-}$males (Fig. 1; Table 2; $p=0.001$; $n=4)$. The effects of the Y365/7F mutation on the expression levels of the $\gamma 2$ and $\alpha 4$ subunits in the brains of age-matched $\mathrm{Y} 365 / 7 \mathrm{~F}^{+1-}$ females were also determined. In contrast to males, $\gamma 2$ subunit expression was significantly reduced in the DG of female $\mathrm{Y} 365 / 7 \mathrm{~F}^{+/-}$mice (Fig. 1 ; Table $2 ; p=0.004 ; n=6$ ). In parallel with this deficit, $\alpha 4$ and $\delta$ subunit expression was both increased in the DG of female $\mathrm{Y} 365 / 7 \mathrm{~F}^{+/-}$mice (Fig. 1; Table 2; $p=0.005 ; n=6$, and $p=0.002 ; n=5$, respectively).

In addition to the $\mathrm{DG}$, the $\alpha 4$ subunit containing $\mathrm{GABA}_{\mathrm{A}} \mathrm{Rs}$ is the major mediator of tonic current in thalamus; thus, we compared the effects of mutating Y365/7F on the expression levels of the $\alpha 4, \gamma 2$, and $\delta$ subunits in this brain region. Consistent with our studies in the DG, expression levels of the $\gamma 2$ subunit were increased in $\mathrm{Y} 365 / 7 \mathrm{~F}^{+/-}$males (Fig. 1; Table 2; $p=0.003 ; n=4$ ), whereas the levels of the $\alpha 4 / \delta$ subunits were both decreased (Fig. 1 ; Table 2; $p=0.006$ and 0.002 , respectively; $n=5$ ). Moreover, in females, the respective mutation decreased $\gamma 2$ subunit levels in the thalamus (Fig. 1; Table 2; $p<0.01 ; n=4$ ) while increasing $\alpha 4 / \delta$ levels (Fig. 1 ; Table $2 ; p=0.007$ and $0.01 ; n=6$ or 7 ).

Collectively, these results reveal that mutation of Y365/7 has gender-specific effects on the steady-state expression levels of $\mathrm{GABA}_{\mathrm{A}} \mathrm{Rs}$ that mediate phasic inhibition and tonic inhibition in both the DG and thalamus.
A

B
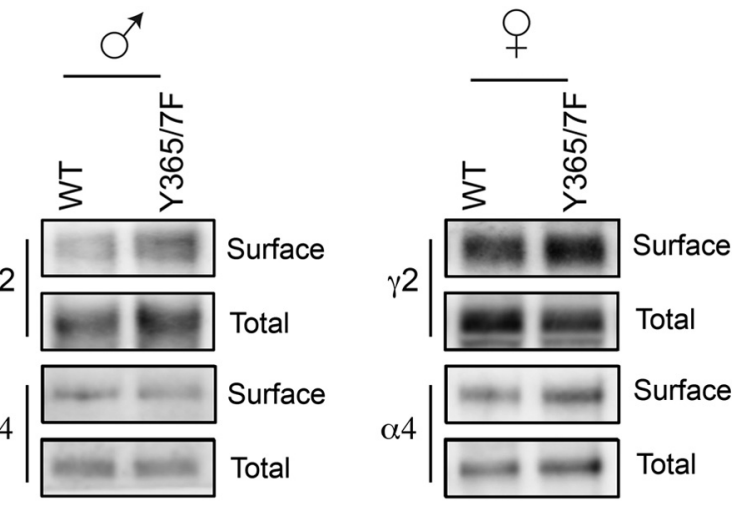

\begin{tabular}{|l|c|c|c|c|}
\hline \hline & $\begin{array}{c}\text { Y2 surface } \\
(\% \mathrm{WT})\end{array}$ & $\begin{array}{c}\text { Y2 total } \\
(\% \mathrm{WT})\end{array}$ & $\begin{array}{c}\text { a4 surface } \\
(\% \mathrm{WT})\end{array}$ & $\begin{array}{c}a 4 \text { total } \\
(\% \mathrm{WT})\end{array}$ \\
\hline $\begin{array}{l}\text { Male } \\
\text { Y365/7F }\end{array}$ & $152.0 \pm 23.1 *$ & $150.0 \pm 26.1 *$ & $78.5 \pm 14.5$ & $118.9 \pm 15.8$ \\
\hline $\begin{array}{l}\text { Female } \\
\text { Y365/7F }\end{array}$ & $113.2 \pm 6.2 *$ & $87.8 \pm 4.4 *$ & $134.4 \pm 8.9 *$ & $111.9 \pm 12.6$ \\
\hline
\end{tabular}

Figure 2. Determination of the cell surface and total expression levels of $G_{A B A} A_{A}$ in the hippocampus of $\mathrm{Y} 365 / 7 \mathrm{~F}^{+/-}$mice. $A$, The $350 \mu$ m hippocampal slices from WT and $\mathrm{Y} 365 / 7 \mathrm{~F}^{+/-}$male and female mice were labeled with NHS-biotin and lysed, and biotinylated proteins were purified on avidin. Cell surface and total fractions were immunoblotted with antibodies against $\mathrm{GABA}_{A}$ receptor, $\alpha 4$ and $\gamma 2$, subunits as indicated. $\boldsymbol{B}$, The total and cell surface levels of the respective subunits in the

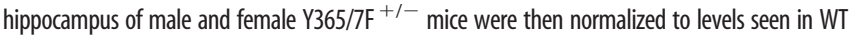
controls (100\%). ${ }^{*} p<0.01$, significantly different from control. $n=4$ or 5 .

\section{The cell surface accumulation of $\mathrm{GABA}_{\mathrm{A}} \mathrm{R}$ subtypes containing $\alpha 4$ subunits is selectively increased in $\mathrm{Y} 365 / 7 \mathrm{~F}^{+1-}$ females}

In addition to immunohistochemistry, we examined whether the cell surface accumulation of the $\alpha 4$ and $\gamma 2$ subunits was modified in whole hippocampal slices from male and female $\mathrm{Y} 365 / 7 \mathrm{~F}^{+/-}$ mice and their WT sibling mice using biotinylation and immunoblotting. Unfortunately, it is not practical to measure these parameters in individual hippocampal structures. Compared with male WT mice, both the cell surface and total expression levels of the $\gamma 2$ subunits were increased in hippocampal slices from male Y365/7 $\mathrm{F}^{+/-}$mice (Fig. 2; $p=0.027$ and $=0.04$ respectively; $n=3-5$ ). In female $\mathrm{Y} 365 / 7 \mathrm{~F}^{+/-}$mice, there was a more modest increase in the cell surface expression levels of the $\gamma 2$ subunit in the whole hippocampus whereas total levels decreased compared with WT mice (Fig. 2; $p=0.03$ and $=0.01$ respectively; $n=3-5$ ). Significantly, an increase in the cell surface accumulation of the $\alpha 4$ subunit specifically seen in the hippocampus of $\mathrm{Y} 365 / 7 \mathrm{~F}^{+/-}$females $(p=0.004, n=4)$ was observed, whereas $\alpha 4$ subunit levels in males were equivalent to those seen in WT mice ( $p=0.095$ ). Total hippocampal levels of the $\alpha 4$ were not modified in either sex ( $p=0.129$ and 0.191 , respectively, for males and females; $n=4$ or 5 ).

Given the limited resolution of these biochemical measurements, our results suggest sex-specific changes in the plasma accumulation of $\mathrm{GABA}_{\mathrm{A}} \mathrm{Rs}$ in the hippocampus of $\mathrm{Y} 365 / 7 \mathrm{~F}^{+/-}$ 
Table 3. Mean change in holding current density with the application of GABA, THIP, or etomidate to hippocampal slices from Y365/7 ${ }^{+/-}$and WT mice ${ }^{a}$

\begin{tabular}{|c|c|c|c|c|c|c|c|c|c|c|c|c|}
\hline & \multicolumn{3}{|c|}{ Heterozygote females } & \multicolumn{3}{|c|}{ WT females } & \multicolumn{3}{|c|}{ Heterozygote males } & \multicolumn{3}{|c|}{ WT males } \\
\hline & Mean & SEM & $n$ & Mean & SEM & $n$ & Mean & SEM & $n$ & Mean & SEM & $n$ \\
\hline GABA $5 \mu \mathrm{M}$ & -1.0 & 0.1 & 12 & -0.5 & 0.2 & 8 & -0.5 & 0.2 & 8 & -0.6 & 0.1 & 9 \\
\hline THIP $1 \mu \mathrm{M}$ & -0.8 & 0.2 & 6 & -0.2 & 0.1 & 6 & -0.3 & 0.1 & 6 & -0.3 & 0.1 & 7 \\
\hline Etomidate $3 \mu \mathrm{m}$ & -0.2 & 0.05 & 8 & -0.04 & 0.02 & 7 & -0.14 & 0.06 & 8 & -0.18 & 0.07 & 8 \\
\hline
\end{tabular}

${ }^{a}$ Data are mean \pm SEM from $3-5$ animals.

mice with females exhibiting enhanced levels of $\mathrm{GABA}_{\mathrm{A}} \mathrm{R}$ subtypes containing $\alpha 4$ subunits whereas males have elevated levels of those incorporating the $\gamma 2$ subunit. Based on our IMF data (Fig. 1 ), these sex-specific changes within the hippocampus are likely to be most pronounced in the DG.

Tonic currents are selectively increased in female $\mathrm{Y} 365 / 7 \mathrm{~F}^{+/-}$mice

To determine whether alterations in $\alpha 4, \delta$, and $\gamma 2$ subunit expression levels in the DG have any functional consequences, we initially compared tonic currents in DGGCs of male and female mice; $5 \mu \mathrm{M}$ GABA produced an inward shift of the holding current. As would be expected with increased $\alpha 4$ expression, the inward shift in holding current density was twofold larger in slices from female $\mathrm{Y} 365 / 7 \mathrm{~F}^{+/-}$mice compared with slices from WT female mice ( $p=0.04$; Table 3; Fig. $3 A, D$ ). GABA-evoked changes in the holding current density were not different between male $\mathrm{Y} 365 / 7 \mathrm{~F}^{+/-}$mice and male WT mice $(p=0.73$, Table 3; Fig. $4 A, D)$. Additionally, there was no difference in GABA-evoked current recorded from DGGCs of WT female mice and those of male WT mice $(p=0.54)$.

Bath application of $1 \mu \mathrm{M}$ THIP $(4,5,6,7-$ tetrahydroisoxazolo[5,4-c]pyridine-3-ol, Gaboxadol), an agonist that shows specificity to receptors containing the extrasynaptic type $\alpha 4 / \delta$ subunits (Jia et al., 2005), also elicited a significant threefold increase in inward current density in DGGCs from female Y365/ $7 \mathrm{~F}^{+1-}$ mice compared with WT female mice $(p=0.017$; Table 3 ; Fig. $3 B, D$ ). Identical changes in holding current were observed with application of THIP to male $\mathrm{Y} 365 / 7 \mathrm{~F}^{+/-}$mice and WT male mice ( $p=0.99$, Table 3; Fig. $4 B, D$ ), consistent with there being no change in the surface expression of the $\alpha 4$ subunit in the hippocampus of male Y365/7F $\mathrm{F}^{+/-}$mice compared with WT male mice.

Tonic inhibitory currents in female $\mathrm{Y} 365 / 7 \mathrm{~F}^{+/-}$mice are more sensitive to GABAergic anesthetics compared with female WT controls

Previous studies have suggested that intravenous anesthetics have a higher efficacy for extrasynaptic $\mathrm{GABA}_{\mathrm{A}}$ Rs compared with synaptic $\mathrm{GABA}_{\mathrm{A}}$ Rs (Bieda and MacIver, 2004; Jia et al., 2008; Belelli et al., 2009; Herd et al., 2009). We next compared the sensitivity of tonic inhibition to modulation by the general intravenous anesthetic etomidate in DG granule neurons recorded in brain slices. Coincident with an increase in $\alpha 4$ subunit expression, we observed an increase in etomidate-sensitive tonic current density recorded from DGGCs in slices from female $\mathrm{Y} 365 / 7 \mathrm{~F}^{+/-}$mice compared with WT female mice (Fig. $3 C, D$ ). Bath application of $3 \mu \mathrm{m}$ etomidate resulted in a shift in the holding current in female WT animals, but a larger current density was evident in female $\mathrm{Y} 365 / 7 \mathrm{~F}^{+--}$mice $(p=0.025$; Table 3; Fig. $3 C, D$ ). In contrast, the etomidate-mediated changes in the holding current density were not different between male Y365/ $7 \mathrm{~F}^{+/-}$mice and male WT mice $(p=0.68$; Table 3; Fig. $4 C, D)$. The etomidate-mediated current was not statistically different between male WT mice and female WT mice $(p=0.11)$. Together, these experiments reveal that the tonic current within the DGCCs of female $\mathrm{Y} 365 / 7 \mathrm{~F}^{+/-}$mice is more sensitive to potentiation by etomidate than their male counterparts.

\section{Female $\mathrm{Y} 365 / 7 \mathrm{~F}^{+/-}$mice have altered phasic inhibition in DGGCs}

We have previously shown that male $\mathrm{Y} 365 / 7 \mathrm{~F}^{+/-}$mice show hippocampal region-specific increased synaptic $\mathrm{GABA}_{\mathrm{A}}$ receptor levels resulting from decreased endocytosis and subsequently increased efficacy of synaptic inhibition (Tretter et al., 2009). Given the modifications in the expression levels of the $\alpha 4$ and $\gamma 2$ subunits in the DG of $Y 365 / 7 \mathrm{~F}^{+/-}$mice (Fig. 1), we compared the properties of inhibitory synaptic currents in DGGCs. The mean sIPSC amplitude was similar in female Y365/7F $\mathrm{F}^{+/-}$mice compared with WT mice $(p=$ 0.12 ; Table 4$)$. The sIPSC frequency is similar $(p=0.93$; Table 4$)$. The sIPSC decays from female $\mathrm{Y} 365 / 7 \mathrm{~F}^{+/-}$mice were significantly 
Table 4. Mean amplitudes, frequencies, and decay times of sIPSCs in Y365/7F ${ }^{+/-}$and WT mice ${ }^{a}$

\begin{tabular}{|c|c|c|c|c|c|c|c|c|c|c|c|c|}
\hline & \multicolumn{3}{|c|}{ Heterozygote females } & \multicolumn{3}{|c|}{ WT females } & \multicolumn{3}{|c|}{ Heterozygote males } & \multicolumn{3}{|c|}{ WT males } \\
\hline & Mean & SEM & $n$ & Mean & SEM & $n$ & Mean & SEM & $\bar{n}$ & Mean & SEM & $n$ \\
\hline sIPSC amplitude (pA) & 29.6 & 1.6 & 19 & 33.3 & 1.7 & 19 & 30.9 & 1.1 & 7 & 30.1 & 1.3 & 11 \\
\hline sIPSC frequency (Hz) & 2.5 & 0.3 & 19 & 2.6 & 0.3 & 19 & 2.9 & 0.3 & 9 & 2.9 & 0.2 & 11 \\
\hline $\mathrm{sIPSC} \tau(\mathrm{ms})$ & $4.0^{*}$ & 0.1 & 16 & 4.8 & 0.2 & 19 & 4.6 & 0.3 & 9 & 4.5 & 0.2 & 11 \\
\hline
\end{tabular}

${ }^{a}$ Data are mean \pm SEM from $5-10$ animals.

${ }^{*} p=0.002$.

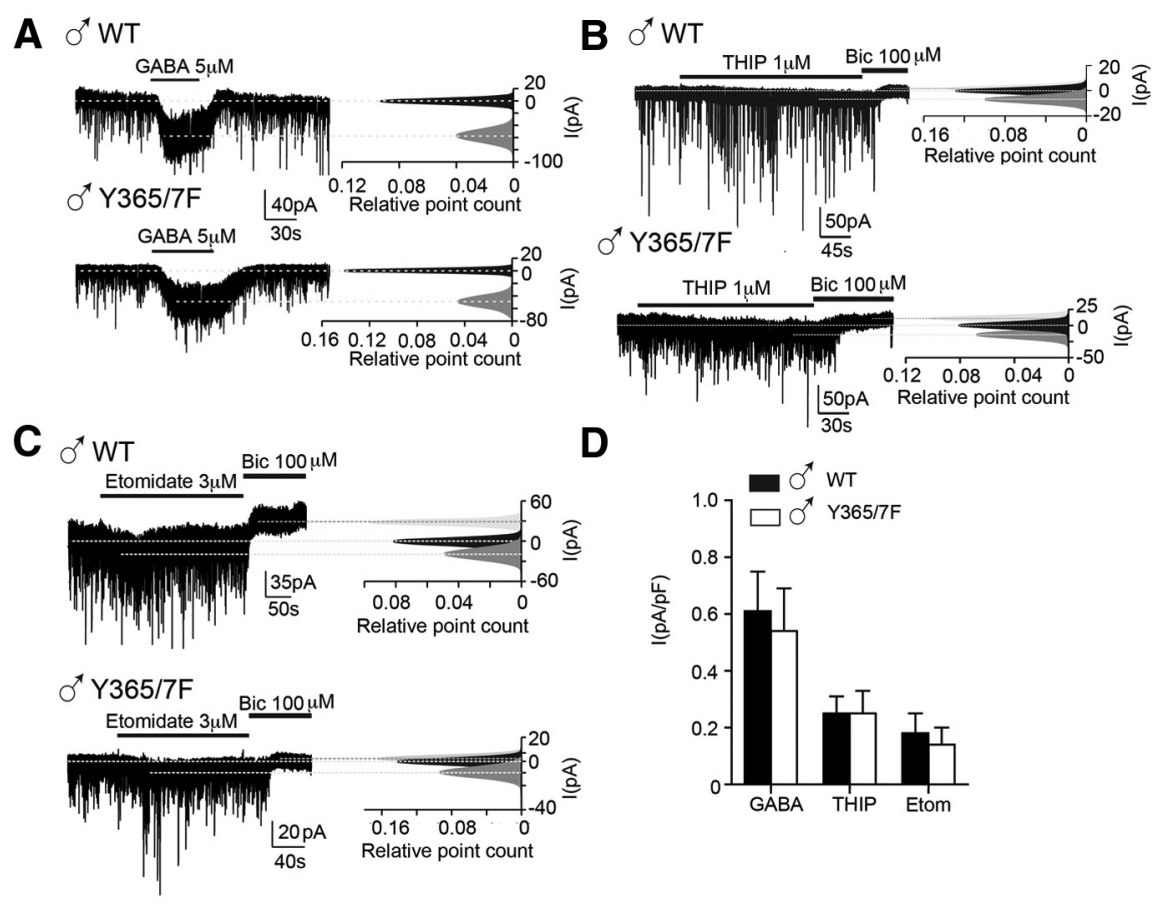

Figure 4. Tonic inhibition in DG granular cells of male $\mathrm{WT}$ and $\mathrm{Y} 365 / 7 \mathrm{~F}^{+/-}$mice. Representative whole-cell voltage-clamp recordings from male WT (top) and Y365/7F ${ }^{+/-}$(bottom) mice. Application of GABA $(\boldsymbol{A})$, THIP $(\boldsymbol{B})$, and etomidate $(\boldsymbol{C})$ induced shifts in holding current. Application of THIP $(\boldsymbol{B})$ and etomidate $(\boldsymbol{C})$ induced shifts in holding current, which were blocked by bicuculline (Bic). Right, Fit to all-point histograms from 10 s period before (black) and during (gray) agonist applications. Histograms were fitted with single Gaussian functions, and means were determined. After subtracting baseline from current evoked by agonist, tonic current was normalized to cell size. D, Summary of effects of GABA, THIP, and etomidate (Etom) on tonic inhibition in male mice. Data plotted are mean \pm SEM; $5-9$ cells per group from 3-5 animals.

faster ( $p=0.002$; Table 4$)$. In contrast, the amplitude, frequency, and decay times of sIPSC in DGGCs were unaltered in male Y365/ $7 \mathrm{~F}^{+/-}$mice relative to WTs (Table 4).

In addition to basal measurements, we compared the effects of etomidate on sIPSC properties in female $\mathrm{Y} 365 / 7 \mathrm{~F}^{+/-}$mice. In DGGCs, anesthetic concentrations of etomidate $(3 \mu \mathrm{M})$ significantly enhanced IPSC amplitude in WT mice [control I = $28.9 \pm 3.8 \mathrm{pA} ; 3 \mu \mathrm{M}$ etomidate $\mathrm{I}=32.3 \pm 4.4 \mathrm{pA} ; p=0.03$ $\left(11.8 \pm 3.8 \%\right.$ increase); $n=6$ ] but not $\mathrm{Y} 365 / 7 \mathrm{~F}^{+/-}$mice [control $\mathrm{I}=26.0 \pm 1.8 \mathrm{pA} ; 3 \mu \mathrm{M}$ etomidate $\mathrm{I}=28.9 \pm 2.3 \mathrm{pA} ; \mathrm{p}=0.08$ $(12.3 \pm 4.4 \%$ increase $) ; n=6]$. However, the modulation of amplitude between $\mathrm{WT}$ and $\mathrm{Y} 365 / 7 \mathrm{~F}^{+/-}$mice was not significant $(p=0.92)$. The effect of etomidate to prolong the decay of sIPSCs of DGGCs of WT mice [control $\tau_{\mathrm{w}}=5.0 \pm 0.5 \mathrm{~ms} ; 3 \mu \mathrm{M}$ etomidate $\tau_{\mathrm{w}}=6.5 \pm 0.5 \mathrm{~ms} ; p=0.03$ (34 $\pm 9 \%$ increase $\left.) ; n=7\right]$ and $\mathrm{Y} 365 / 7 \mathrm{~F}^{+/-}$mice [control $\tau_{\mathrm{w}}=4.0 \pm 0.2 \mathrm{~ms} ; 3 \mu \mathrm{M}$ etomidate $\tau_{\mathrm{w}}=5.8 \pm 0.7 \mathrm{~ms} ; p=0.04(42 \pm 14 \%$ increase $\left.) ; n=5\right]$ was not significantly different $\left(p=0.61\right.$, WT vs Y365/7F $\left.{ }^{+/-}\right)$. Collectively, these results reveal that the properties of phasic inhibition are selectively modified in female $\mathrm{Y} 365 / 7 \mathrm{~F}^{+/-}$mice but that etomidate-mediated modulation of IPSCs is not changed as a function of genotype.

\section{LTP is absent in the DG of female $\mathrm{Y} 365 / 7 \mathrm{~F}^{+/-}$mice}

To examine the consequence of the increased tonic current in the DGGCs from female $\mathrm{Y} 365 / 7 \mathrm{~F}^{+/-}$mice on a circuit level, we examined LTP induced in the perforant path-DGGC pathway using the extracellular field potential recording technique. LTP was induced in female WT mice, at 60 min after high-frequency stimulation (113 $\pm 3 \%$ of baseline, $n=4)$, whereas no LTP was induced in the perforant path-DGGC pathway from female Y365/7F $\mathrm{F}^{+/-}$mice $(97 \pm 3 \%$ of baseline, $n=6, p=0.007$; Fig. $5 A$ ). The absence of LTP in female $\mathrm{Y} 365 / 7 \mathrm{~F}^{+/-}$mice compared with female WT mice may be the result of changes in presynaptic properties occurring in Y365/7 $\mathrm{F}^{+/-}$mice. To determine whether the lack of LTP in female $\mathrm{Y} 365 / 7 \mathrm{~F}^{+/-}$mice is the result of any genotype change in presynaptic properties, we examined paired-pulse stimulation. With a $50 \mathrm{~ms}$ interpulse interval, the paired-pulse ratio was not different between female $\mathrm{Y} 365 / 7 \mathrm{~F}^{+/-}$mice and WT mice (Fig. 5B). Therefore, the net increase in tonic inhibition in the DG of female $\mathrm{Y} 365 / 7 \mathrm{~F}^{+/-}$mice is sufficient to modify circuit activity and synaptic plasticity.

\section{Enhanced tonic inhibition is correlated with increased} sensitivity to GABAergic anesthetics

Given the increased levels of tonic inhibition and its enhanced sensitivity to etomidate in $\mathrm{Y} 365 / 7 \mathrm{~F}^{+/-}$females, we examined hypnotic sensitivity using the loss of righting reflex assay. In females, two-way ANOVA demonstrated significant main effects of etomidate dose $\left(F_{(2,43)}=29.5, p<0.0001\right)$ and genotype $\left(F_{(1,43)}=16.4, p=0.0002\right)$ without any significant interaction between factors $\left(F_{(2,43)}=1.4, p=0.26\right)$. After administration of $2.5,5.0$, and $10.0 \mathrm{mg} / \mathrm{kg}$ of intravenous etomidate, $\mathrm{Y} 365 / 7 \mathrm{~F}^{+/-}$ females remained obtunded for 8, 3, and 1.6 times, respectively, as long as WT siblings (Fig. 6A). Conversely, in $\mathrm{Y} 365 / 7 \mathrm{~F}^{+/-}$ males, two-way ANOVA revealed no significant effect of genotype on the duration of anesthetic obtundation $\left(F_{(1,36)}=0.02\right.$, $p=0.89)$ and no interaction between genotype and etomidate dose $\left(F_{(2,36)}=0.06, p=0.94\right)$. However, as expected, etomidate dose did significantly affect the duration of loss of righting reflex $\left(F_{(2,36)}=26.9, p<0.0001\right)$ in males just as in females with larger doses causing a prolonged duration of obtundation (Fig. 6B). 

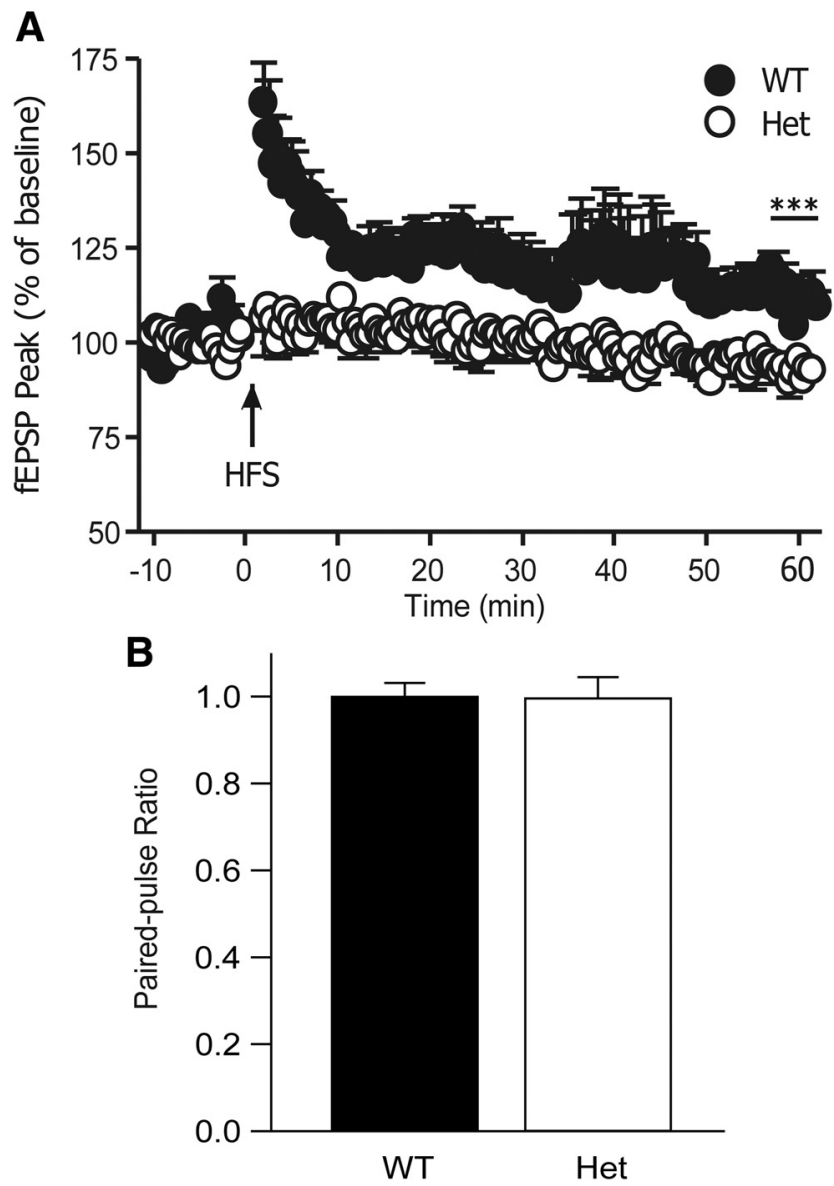

Figure 5. LTP is suppressed in the DG of the female $\mathrm{Y} 365 / 7 \mathrm{~F}^{+/-}$mice. $A$, LTP was induced by high-frequency stimulation (arrow) of medial perforant pathway. Data were recorded from 4 WT and 6 Y $365 / 7 \mathrm{~F}^{+/-}$mice, respectively. Values are mean \pm SEM. ${ }^{* * *} p=0.007$ ( $t$ test). $\boldsymbol{B}$, Pair-pulse facilitation ( $50 \mathrm{~ms}$ interpulse interval) was not significantly different between geno-

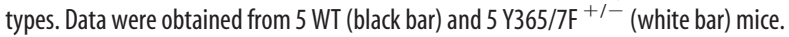

Having shown hypersensitivity to the hypnotic effects of etomidate uniquely in females, we tested anesthetic sensitivity in Y365/7F $\mathrm{F}^{+/-}$mice and WT siblings using propofol, a second GABAergic anesthetic with less selectivity for $\mathrm{GABA}_{\mathrm{A}}$ receptors than etomidate (Krasowski and Harrison, 1999). After propofol $20 \mathrm{mg} / \mathrm{kg}$ i.v., two-way ANOVA found no significant main effects of genotype $\left(F_{(1,25)}=2.25, p=0.15\right)$ or gender $\left(F_{(1,25)}=0.39\right.$, $p=0.53)$, but a significant interaction between the factors $\left(F_{(1,25)}=8.9, p=0.0063\right)$. As with etomidate, $\mathrm{Y} 365 / 7 \mathrm{~F}^{+/-} \mathrm{fe}-$ male mice were also hypersensitive to the hypnotic properties of propofol. Y365/7F $\mathrm{F}^{+/-}$females remained obtunded for 1.7 times as long as WT siblings, whereas an identical dose of propofol did not differentially affect the duration of anesthesia in males (Fig. 6C). There were no significant changes in core body temperature from preanesthetic induction to postemergence effects as a function of gender $\left(F_{(1,115)}=0.51, p=0.48\right)$ or genotype $\left(F_{(1,115)}=0.86, p=\right.$ $0.36)$, and no significant interaction between genotype and gender on temperature $\left(F_{(1,115)}=0.03, p=0.87\right)$. Thus, enhanced expression of $\alpha 4$ containing $\mathrm{GABA}_{\mathrm{A}}$ Rs and the subsequent enhanced tonic inhibition in $\mathrm{Y} 365 / 7 \mathrm{~F}^{+/-}$is selectively correlated with increased hypnotic sensitivity to etomidate and propofol.

Enhanced tonic inhibition is associated with hypersensitivity to the amnestic effects of GABAergic anesthetics

Contextual fear conditioning, which depends upon the hippocampus, was examined to assay freezing behavior as a function
A

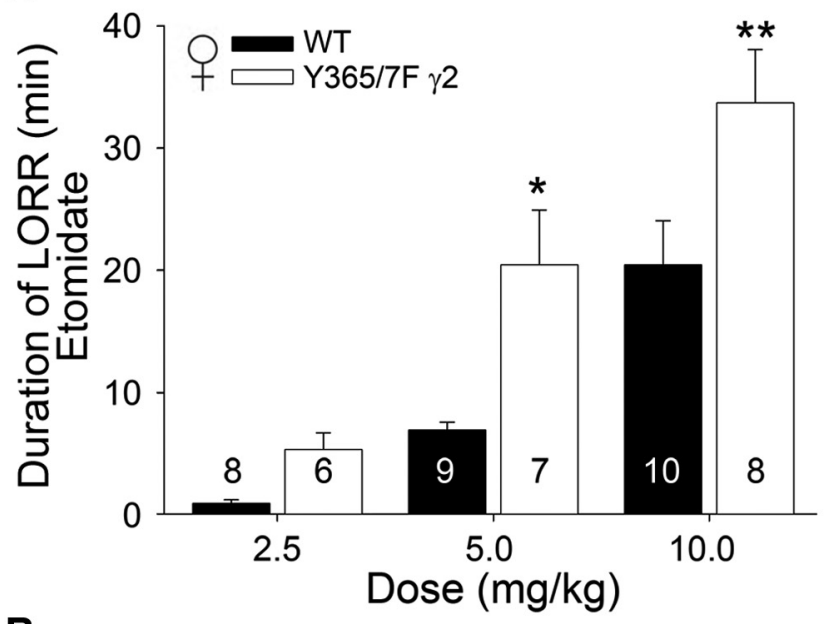

B

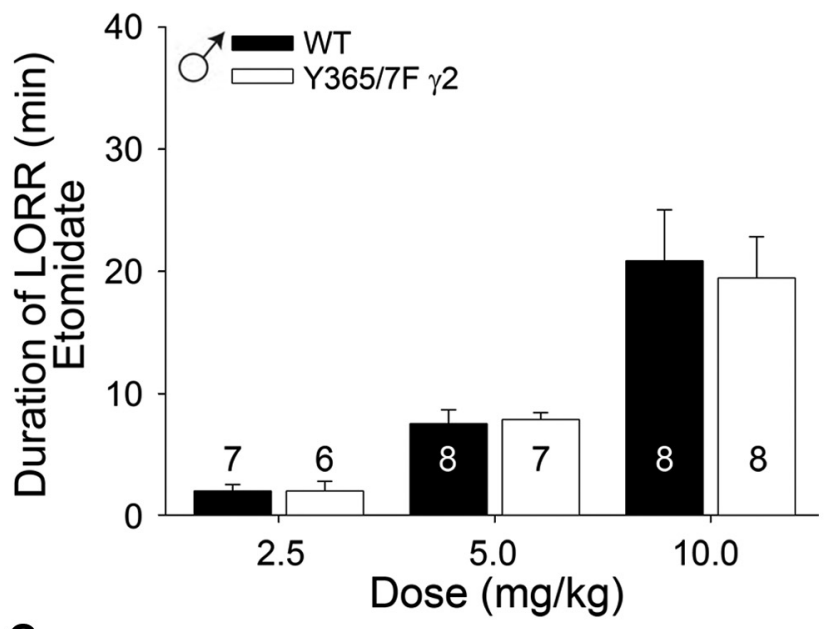

C

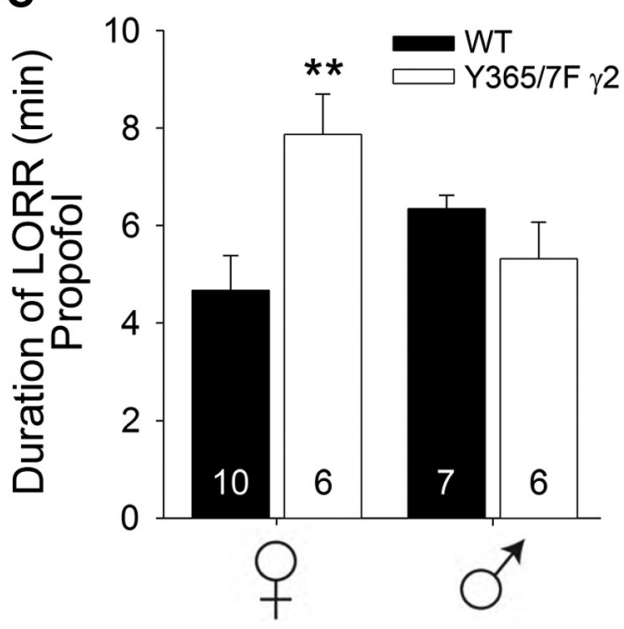

Figure 6. Female $\mathrm{Y} 365 / 7 \mathrm{~F}^{+/-}$mice exhibit hypersensitivity to the hypnotic effects of etomidate and propofol. Duration of the loss of righting reflex (LORR) induced by intravenous administration of etomidate in female $(\boldsymbol{A})$ and male $(\boldsymbol{B})$ WT (black bar) mice and $\mathrm{Y} 365 / 7 \mathrm{~F}^{+/-}$ siblings (white bar). Two-way ANOVA demonstrated significant effects of genotype and etomidate dose on LORR. ${ }^{*} p<0.05$, in Y365/7 ${ }^{+/}$mice compared with corresponding WT (Bonferroni post-test). ${ }^{* *} p<0.01$, in $\mathrm{Y} 365 / 7^{+/-}$mice compared with corresponding WT (Bonferroni post-test). C, Duration of loss of righting reflex induced by intravenous administration of $20 \mathrm{mg} / \mathrm{kg}$ propofol in WT (black bar) mice and $\mathrm{Y} 365 / 7 \mathrm{~F}^{+/-}$siblings (white bar). Twoway ANOVA demonstrates a significant interaction between genotype and gender. ${ }^{* *} p<0.01$ (Bonferroni post-test). The number of mice in each group is displayed within each bar. 
of genotype in the presence and absence of an amnestic dose of etomidate ( $4 \mathrm{mg} / \mathrm{kg}$ i.p.). Baseline freezing was calculated as the percent freezing during the first 2 min of contextual fear conditioning training averaged among all groups of one gender. Baseline freezing did not differ between vehicle and etomidate treatment groups $(1.46 \pm 0.87 \%$ and $3.70 \pm 1.55 \%$, respectively; Fig. $7 A, D)$, or between WT and $\mathrm{Y} 365 / 7 \mathrm{~F}^{+/-}(1.37 \pm 0.40 \%$ and $2.56 \pm 1.29 \%$, respectively; Fig. $7 A, D)$. We also examined the extent of freezing in response to the stimulus during training (average of last $3 \mathrm{~min}$ of training) to ensure that WT and Y365/ $7 \mathrm{~F}^{+/-}$mice did not differ in their response to shock, and further to confirm that mice treated with etomidate did not display a diminished behavioral response to the shock resulting from lingering amnestic effects. Two-way repeated-measures ANOVA on the shock response during training did not demonstrate a significant main effect of genotype within either gender (female $F_{(1,20)}=$ $0.3, p=0.580$; male $F_{(1,35)}=0.9, p=0.343$; Fig. $\left.7 A, D\right)$. However, in females, we did observe a significant main effect of treatment $\left(F_{(1,20)}=6.9, p=0.014\right)$, where female mice treated with etomidate showed an enhanced average freezing response to shock during training compared with vehicle control females (41.18 \pm $2.24 \%$ and $29.24 \pm 1.12 \%$; Fig. $6 A$ ).

During contextual fear conditioning testing in females, two-way ANOVA demonstrated significant main effects of genotype $\left(F_{(1,20)}=5.5, p=0.032\right)$ and treatment $\left(F_{(1,20)}=28.7\right.$, $p<0.001)$ without any significant interaction between factors $\left(F_{(2,20)}=0.8, p=0.799\right)$. Female WT $(57.04 \pm 5.5 \%)$ and $\mathrm{Y} 365 / 7 \mathrm{~F}^{+/-}(48.56 \pm 5.9 \%)$ mice treated with vehicle did not significantly differ in percent freezing $(p=0.311$; Fig. $7 B, C)$, suggesting that both genotypes have intact fear memory. Mice treated with etomidate showed a significant reduction in percent freezing $(30.8 \pm 6.0 \%, p=0.013)$ compared with female WT mice treated with vehicle $(57.0 \pm 5.5 \%$; Fig. $6 B, C)$. Female $\mathrm{Y} 365 / 7 \mathrm{~F}^{+/-}$mice treated with etomidate also showed a significant reduction in percent freezing $(11.8 \pm 6.0 \%, p=$ 0.001 ) compared with female $\mathrm{Y} 365 / 7 \mathrm{~F}^{+/-}$mice treated with vehicle $(48.6 \pm 6.0 \%)$. In addition, female $\mathrm{Y} 365 / 7 \mathrm{~F}^{+/-}$mice treated with etomidate also showed a significant reduction in percent freezing $(p=0.039)$ compared with female WT mice treated with etomidate, suggesting that the amnestic effects of etomidate have a more profound effect on mice heterozygous for the Y356/7 mutation.

In males, two-way ANOVA demonstrated a significant main effect of treatment $\left(F_{(1,35)}=15.59, p<0.001\right)$, without a significant main effect of genotype $\left(F_{(1,35)}=3.8, p=0.059\right)$, or significant interaction between factors $\left(F_{(2,35)}=2.8, p=0.103\right)$ during contextual fear conditioning testing. Whereas vehicle-treated WT males exhibited normal recall $(64.0 \pm 6.2 \%)$, Y365/7F ${ }^{+/-}$ $(42.6 \pm 5.0 \%)$ were found to have a significant memory impairment $(p=0.011$; Fig. $7 E, F)$. In WT males, treatment with etomidate produced a significant reduction in percent freezing $(30.9 \pm 6.1 \%, p=0.002)$ compared with male WT mice treated with vehicle $(64.0 \pm 6.2 \%$; Fig. $7 E, F)$ demonstrating the amnestic effects of etomidate. Interestingly, percent freezing in male Y365/7F ${ }^{+/-}$mice treated with etomidate $(29.3 \pm 6.1 \%)$ did not significantly differ from either vehicle-treated male $\mathrm{Y} 365 / 7 \mathrm{~F}^{+/-}$ mice $(p=0.229)$, or etomidate-treated WT mice $(p=0.854)$. This may suggest that either the male $\mathrm{Y} 365 / 7 \mathrm{~F}^{+/-}$mice are less sensitive to the amnestic effects of etomidate, or perhaps that the amnestic effects of etomidate are masked by the basal memory impairment observed in this strain.

\section{Discussion}

Intravenous anesthetics are thought to mediate their actions in part by potentiating inhibitory neurotransmission mediated by $\mathrm{GABA}_{\mathrm{A}}$ Rs. Here, we have assessed whether these agents mediate their spectrum of effects via selectively potentiating phasic and or tonic forms of GABAergic inhibition. To do so, we used mice in which the membrane trafficking of $\gamma 2$ subunit-containing subtypes, accepted mediators of phasic inhibition, has been modified via mutation of Y365/7 within the intracellular domain of this subunit. Y365/7 mediate high-affinity binding to clathrin adaptors and thereby promote endocytic trafficking of $\mathrm{GABA}_{\mathrm{A}}$ Rs. Importantly, their mutation to phenylalanine residues or their phosphorylation by Src, such as kinase, reduces the affinity for clathrin adaptors, increasing the receptors cell surface levels (Kittler et al., 2008; Jurd et al., 2010). Consistent with this, $\mathrm{Y} 365 / 7 \mathrm{~F}^{+/-}$males have elevated levels of $\gamma 2$ subunit expression and phasic inhibition in specific regions, such as the CA3 (Tretter et al., 2009). Here, we reveal that this mutation has gender-selective effects on the expression levels of $\mathrm{GABA}_{\mathrm{A}} \mathrm{R}$ subunits that mediate tonic inhibition. Specifically, Y365/ $7 \mathrm{~F}^{+/-}$males had a significant reduction in $\alpha 4$ and $\delta$ subunit expression within the DG and thalamus, although this did not cause a reduction in the surface expression of the $\alpha 4$ subunit in the hippocampus. In contrast, the respective mutation in female Y365/ $7 \mathrm{~F}^{+/-}$mice reduced $\gamma 2$ subunit expression in these brain regions but dramatically increased levels of the $\alpha 4$ and $\delta$ subunits. Importantly, these gender-specific changes in $\alpha 4$ subunit expression are localized to brain structures that have been suggested to contribute to changes between conscious and anesthetic-induced unconscious states, as well as memory consolidation (Benke et al., 1997; Franks, 2008).

The mechanisms underlying both the reciprocal relationship between phasic and tonic subunit expression, and genderspecific differences in $\alpha 4$ subunit expression upon mutation of $\gamma 2$ remain obscure. Studies examining GABA $_{\mathrm{A}} \alpha 4$ knock-out mice have demonstrated increases in the expression of the phasic subunits $\gamma 2$ and $\alpha 2$ (Suryanarayanan et al., 2011), whereas significant increases in expression of $\alpha 4$ have been noted in the $\mathrm{GABA}_{\mathrm{A}} \alpha 2$ knock-out mice (Panzanelli et al., 2011). In addition, $\mathrm{GABA}_{\mathrm{A}} \delta$ subunit knock-out mice have decreased $\alpha 4$ subunit expression but a compensatory increase in $\gamma 2$ subunit expression (Tretter et al., 2001; Peng et al., 2002). These reciprocal changes may reflect assembly and trafficking "competition" between individual subunits, or a more complex compensatory change acting to increase phasic inhibition when tonic is impaired, and vice versa. Other unknown compensatory changes may contribute to the phenotype of the Y365/7F $\mathrm{F}^{+/-}$mice. However, given the dose of etomidate and propofol used, in addition to the changes in expression of anesthetic-sensitive subunits and the pharmacological characteristics of the tonic currents, the most probable explanation is an increase in tonic inhibition mediated by $\alpha 4$ subunit-containing $\mathrm{GABA}_{\mathrm{A}} \mathrm{Rs}$. With regard to the gender-specific differences, previous studies have demonstrated that the estrus cycle can exert powerful effects on the expression levels of $\mathrm{GABA}_{\mathrm{A}}$ Rs (Maguire and Mody, 2007, 2008). However, the estrus cycle is unlikely to explain our results because male and female animals are raised in isolation; and consequently, we did not observe regular cycling in females (see Materials and Methods). Thus, it is conceivable that, in addition to estrus, there may be a hormonally regulated difference in $\mathrm{GABA}_{\mathrm{A}} \mathrm{R}$ trafficking, assembly, or phosphorylation that differs between genders (Cahill, 2006).

To determine the functional consequence of these genderspecific changes in $\alpha 4$ subunit expression, we performed brain 
slice electrophysiology experiments to quantify the synaptic and extrasynaptic $\mathrm{GABA}_{\mathrm{A}} \mathrm{R}$-mediated currents between male and female $\mathrm{Y} 365 / 7 \mathrm{~F}^{+/-}$mice. Consistent with our biochemical measurements, we observed that the tonic current was selectively increased in DGGCs from $\mathrm{Y} 365 / 7 \mathrm{~F}^{+/-}$females relative to WT mice and $\mathrm{Y} 365 / 7 \mathrm{~F}^{+/-}$males. A preliminary study has also found an increase in GABAergic tonic current in thalamic relay neurons from Y365/ $7 \mathrm{~F}^{+/-}$females but not male Y365/ $7 \mathrm{~F}^{+/-}$mice compared with controls (Nani et al., 2012). These results suggest an increase in $\alpha 4$ and $\delta$ subunitcontaining extrasynaptic $\mathrm{GABA}_{\mathrm{A}} \mathrm{Rs}$ in an area of the brain associated with anesthetic-mediated loss of consciousness and amnesia. Collectively, these data point to the increase in expression of functional $\alpha 4$ and $\delta$ subunitcontaining $\mathrm{GABA}_{\mathrm{A}} \mathrm{Rs}$ in the membrane of DGGCs and thalamic neurons and is consistent with our biochemical measurements. However, we did not observe a corresponding decrease in tonic current despite a decreased expression observed in our immunohistochemistry experiments. As immunohistochemistry cannot distinguish between subunit surface expression from total subunit expression, the data indicate that, although the expression of $\alpha 4$ and $\delta$ subunits is down in male $\mathrm{Y} 365 / 7 \mathrm{~F}^{+/-}$mice, there was little change in functional $\alpha 4$ and $\delta$ subunit-containing $\mathrm{GABA}_{\mathrm{A}} \mathrm{Rs}$. This is further supported by our biotinylation data showing no change in surface $\alpha 4$ subunit expression in male $\mathrm{Y} 365 / 7 \mathrm{~F}^{+/-}$ mice compared with WT mice.

In addition to the increase in tonic current, we also noted that sIPSC decay was faster in DGGCs from Y365/7F ${ }^{+/-}$females. This change in IPSC kinetics may be the result of the reduction of $\gamma 2$ subunit expression. However, the increase in $\alpha 4$ subunit expression may also lead to the formation of synaptic $\alpha 4 \beta \gamma 2$-containing synaptic receptors that have altered kinetics (Liang et al., 2007).

To assess whether this increase in tonic inhibition impacts on neuronal excitability, we examined LTP induced in the perforant path-DGGC pathway. Although LTP was routinely seen in WT females, no LTP was seen in $\mathrm{Y}^{3} 65 / 7 \mathrm{~F}^{+/-}$females. This deficit is likely to be postsynaptic in nature as the paired-pulse ratio was similar between WT and mutant females. Collectively, these results suggest that the net increase in tonic inhibition in the DG of female $\mathrm{Y} 365 / 7 \mathrm{~F}^{+/-}$mice is sufficient to modify circuit activity and synaptic plasticity.

Documented studies suggest that intravenous anesthetics have a higher efficacy for extrasynaptic $\mathrm{GABA}_{\mathrm{A}}$ Rs compared with their synaptic counterparts (Bieda and MacIver, 2004; Jia et al., 2008; Belelli et al., 2009; Herd et al., 2009). Consistent with this, the etomidate-sensitive tonic current was significantly enhanced in $\mathrm{Y} 365 / 7 \mathrm{~F}^{+/-}$females. In contrast, the ability of etomidate to potentiate phasic currents was comparable between WT and $\mathrm{Y} 365 / 7 \mathrm{~F}^{+/-}$females. Collectively, our re- sults reveal that tonic current and its sensitivity to modulation by intravenous anesthetics are selectively increased in Y365/ $7 \mathrm{~F}^{+/-}$females.

To assess whether this enhancement of tonic current modifies sensitivity to intravenous anesthetics, we compared the sensitivity of male and female Y376/7F mice to the hypnotic effects of etomidate and propofol. Y365/7F ${ }^{+/-}$females exhibited hypersensitivity to the hypnotic effects of both agents, a phenomenon not replicated in $\mathrm{Y} 365 / 7 \mathrm{~F}^{+/-}$males. Although enhancing GABA signaling within the septohippocampal system is known to increase the hypnotic potency of propofol, pentobarbital, and volatile anesthetics (Ma et al., 2002), a specific role for enhancing tonic GABA signaling within DG has not been previously noted. Enhanced tonic inhibition in thalamus (Fiset et al., 1999; Alkire and Miller, 2005; Boveroux et al., 2010) might prove to be the critical neuroanatomic loci for altering hypnotic sensitivity in this mouse model.

In addition to measuring hypnosis, we also compare the amnestic effects of etomidate between males and females of both genotypes using contextual fear conditioning in the presence of an amnestic dose of etomidate ( $4 \mathrm{mg} / \mathrm{kg}$ i.p.). Baseline measurements revealed female $\mathrm{Y} 365 / 7 \mathrm{~F}^{+/-}$had intact fear memory. However, the amnestic effects of etomidate were more pronounced in $\mathrm{Y} 365 / 7 \mathrm{~F}^{+/-}$females. Collectively, these gender-specific effects strongly suggest that the ability of etomidate to induce hypnosis and amnesia are dependent on $\alpha 4$ subunit containing $\mathrm{GABA}_{\mathrm{A}} \mathrm{Rs}$ within the $\mathrm{DG}$ and thalamus that are accepted mediators of tonic inhibition. 
In conclusion, our results using Y365/7F mutant mice are consistent with a specific role for tonic inhibition governed by $\alpha 4$ subunit in mediating the hypnotic and amnestic actions of intravenous anesthetics.

\section{References}

Alkire MT, Miller J (2005) General anesthesia and the neural correlates of consciousness. Prog Brain Res 150:229-244. CrossRef Medline

Belelli D, Harrison NL, Maguire J, Macdonald RL, Walker MC, Cope DW (2009) Extrasynaptic GABAA receptors: form, pharmacology, and function. J Neurosci 29:12757-12763. CrossRef Medline

Bencsits E, Ebert V, Tretter V, Sieghart W (1999) A significant part of native $\gamma$-aminobutyric acidA receptors containing $\alpha 4$ subunits do not contain gamma or $\delta$ subunits. J Biol Chem 274:19613-19616. CrossRef Medline

Benke D, Michel C, Mohler H (1997) GABA(A) receptors containing the $\alpha 4$-subunit: prevalence, distribution, pharmacology, and subunit architecture in situ. J Neurochem 69:806-814. CrossRef Medline

Bieda MC, MacIver MB (2004) Major role for tonic GABAA conductances in anesthetic suppression of intrinsic neuronal excitability. J Neurophysiol 92:1658-1667. CrossRef Medline

Bieda MC, Su H, Maciver MB (2009) Anesthetics discriminate between tonic and phasic $\gamma$-aminobutyric acid receptors on hippocampal CA1 neurons. Anesth Analg 108:484-490. CrossRef Medline

Boveroux P, Vanhaudenhuyse A, Bruno MA, Noirhomme Q, Lauwick S, Luxen A, Degueldre C, Plenevaux A, Schnakers C, Phillips C, Brichant JF, Bonhomme V, Maquet P, Greicius MD, Laureys S, Boly M (2010) Breakdown of within- and between-network resting state functional magnetic resonance imaging connectivity during propofol-induced loss of consciousness. Anesthesiology 113:1038-1053. CrossRef Medline

Brown EN, Purdon PL, Van Dort CJ (2011) General anesthesia and altered states of arousal: a systems neuroscience analysis. Annu Rev Neurosci 34:601-628. CrossRef Medline

Cahill L (2006) Why sex matters for neuroscience. Nat Rev Neurosci 7:477484. CrossRef Medline

Caligioni CS (2009) Assessing reproductive status/stages in mice. Curr Protoc Neurosci Appendix 4:Appendix 4I. CrossRef Medline

Champlin AK (1971) Suppression of oestrus in grouped mice: the effects of various densities and the possible nature of the stimulus. J Reprod Fertil 27:233-241. CrossRef Medline

Chandra D, Jia F, Liang J, Peng Z, Suryanarayanan A, Werner DF, Spigelman I, Houser CR, Olsen RW, Harrison NL, Homanics GE (2006) GABAA receptor $\alpha$ 4 subunits mediate extrasynaptic inhibition in thalamus and dentate gyrus and the action of gaboxadol. Proc Natl Acad Sci U S A 103:15230-15235. CrossRef Medline

Cheng VY, Martin LJ, Elliott EM, Kim JH, Mount HT, Taverna FA, Roder JC, Macdonald JF, Bhambri A, Collinson N, Wafford KA, Orser BA (2006) $\alpha 5$ GABAA receptors mediate the amnestic but not sedative-hypnotic effects of the general anesthetic etomidate. J Neurosci 26:3713-3720. CrossRef Medline

Fiset P, Paus T, Daloze T, Plourde G, Meuret P, Bonhomme V, Hajj-Ali N, Backman SB, Evans AC (1999) Brain mechanisms of propofol-induced loss of consciousness in humans: a positron emission tomographic study. J Neurosci 19:5506-5513. Medline

Franks NP (2008) General anaesthesia: from molecular targets to neuronal pathways of sleep and arousal. Nat Rev Neurosci 9:370-386. CrossRef Medline

Herd MB, Foister N, Chandra D, Peden DR, Homanics GE, Brown VJ, Balfour DJ, Lambert JJ, Belelli D (2009) Inhibition of thalamic excitability by 4,5,6,7-tetrahydroisoxazolo[4,5-c]pyridine-3-ol: a selective role for $\delta$-GABA(A) receptors. Eur J Neurosci 29:1177-1187. CrossRef Medline

Hu FY, Hanna GM, Han W, Mardini F, Thomas SA, Wyner AJ, Kelz MB (2012) Hypnotic hypersensitivity to volatile anesthetics and dexmedetomidine in dopamine $\beta$-hydroxylase knockout mice. Anesthesiology 117:1006-1017. CrossRef Medline

Jacob TC, Moss SJ, Jurd R (2008) GABA(A) receptor trafficking and its role in the dynamic modulation of neuronal inhibition. Nat Rev Neurosci 9:331-343. CrossRef Medline

Jia F, Pignataro L, Schofield CM, Yue M, Harrison NL, Goldstein PA (2005) An extrasynaptic GABAA receptor mediates tonic inhibition in thalamic VB neurons. J Neurophysiol 94:4491-4501. CrossRef Medline

Jia F, Yue M, Chandra D, Homanics GE, Goldstein PA, Harrison NL (2008)
Isoflurane is a potent modulator of extrasynaptic $\mathrm{GABA}(\mathrm{A})$ receptors in the thalamus. J Pharmacol Exp Ther 324:1127-1135. CrossRef Medline

Jurd R, Moss SJ (2010) Impaired GABA(A) receptor endocytosis and its correlation to spatial memory deficits. Commun Integr Biol 3:176-178. CrossRef Medline

Jurd R, Arras M, Lambert S, Drexler B, Siegwart R, Crestani F, Zaugg M, Vogt KE, Ledermann B, Antkowiak B, Rudolph U (2003) General anesthetic actions in vivo strongly attenuated by a point mutation in the GABA(A) receptor $\beta 3$ subunit. FASEB J 17:250-252. CrossRef Medline

Jurd R, Tretter V, Walker J, Brandon NJ, Moss SJ (2010) Fyn kinase contributes to tyrosine phosphorylation of the GABA(A) receptor $\gamma 2$ subunit. Mol Cell Neurosci 44:129-134. CrossRef Medline

Kittler JT, Chen G, Kukhtina V, Vahedi-Faridi A, Gu Z, Tretter V, Smith KR, McAinsh K, Arancibia-Carcamo IL, Saenger W, Haucke V, Yan Z, Moss SJ (2008) Regulation of synaptic inhibition by phospho-dependent binding of the AP2 complex to a YECL motif in the GABAA receptor gamma2 subunit. Proc Natl Acad Sci U S A 105:3616-3621. CrossRef Medline

Krasowski MD, Harrison NL (1999) General anaesthetic actions on ligandgated ion channels. Cell Mol Life Sci 55:1278-1303. CrossRef Medline

Liang J, Suryanarayanan A, Abriam A, Snyder B, Olsen RW, Spigelman I (2007) Mechanisms of reversible GABAA receptor plasticity after ethanol intoxication. J Neurosci 27:12367-12377. CrossRef Medline

Ma J, Shen B, Stewart LS, Herrick IA, Leung LS (2002) The septohippocampal system participates in general anesthesia. J Neurosci 22:RC200. Medline

Maguire J, Mody I (2007) Neurosteroid synthesis-mediated regulation of GABA(A) receptors: relevance to the ovarian cycle and stress. J Neurosci 27:2155-2162. CrossRef Medline

Maguire J, Mody I (2008) GABA(A)R plasticity during pregnancy: relevance to postpartum depression. Neuron 59:207-213. CrossRef Medline

Marsden HM, Bronson FH (1964) Estrous synchrony in mice: alteration by exposure to male urine. Science 144:1469. CrossRef Medline

Marsden HM, Bronson FH (1965) The synchrony of oestrus in mice: relative roles of the male and female environments. J Endocrinol 32:313-319. CrossRef Medline

Martin LJ, Oh GH, Orser BA (2009) Etomidate targets $\alpha 5 \gamma$-aminobutyric acid subtype A receptors to regulate synaptic plasticity and memory blockade. Anesthesiology 111:1025-1035. CrossRef Medline

McLean AC, Valenzuela N, Fai S, Bennett SA (2012) Performing vaginal lavage, crystal violet staining, and vaginal cytological evaluation for mouse estrous cycle staging identification. J Vis. Exp 67:e4389. CrossRef Medline

Nani F, Tretter V, Moss SJ, Smart TG (2012) Impaired tyrosine phosphorylation of synaptic GABA receptors promotes tonic inhibition in the thalamus (Program No. 138.08). 2012 Neuroscience Meeting Planner. New Orleans: Society for Neuroscience.

Olsen RW, Sieghart W (2008) International Union of Pharmacology. LXX. Subtypes of $\gamma$-aminobutyric acid(A) receptors: classification on the basis of subunit composition, pharmacology, and function. Update. Pharmacol Rev 60:243-260. CrossRef Medline

Panzanelli P, Gunn BG, Schlatter MC, Benke D, Tyagarajan SK, Scheiffele P, Belelli D, Lambert JJ, Rudolph U, Fritschy JM (2011) Distinct mechanisms regulate GABAA receptor and gephyrin clustering at perisomatic and axoaxonic synapses on CA1 pyramidal cells. J Physiol 589:4959-4980. CrossRef Medline

Peng Z, Hauer B, Mihalek RM, Homanics GE, Sieghart W, Olsen RW, Houser CR (2002) GABA(A) receptor changes in ssubunit-deficient mice: altered expression of alpha 4 and gamma 2 subunits in the forebrain. J Comp Neurol 446:179-197. CrossRef Medline

Semyanov A, Walker MC, Kullmann DM, Silver RA (2004) Tonically active GABA A receptors: modulating gain and maintaining the tone. Trends Neurosci 27:262-269. CrossRef Medline

Steriade M, McCormick DA, Sejnowski TJ (1993) Thalamocortical oscillations in the sleeping and aroused brain. Science 262:679-685. CrossRef Medline

Sun Y, Chen J, Pruckmayr G, Baumgardner JE, Eckmann DM, Eckenhoff RG, Kelz MB (2006) High throughput modular chambers for rapid evaluation of anesthetic sensitivity. BMC Anesthesiol 6:13. CrossRef Medline

Suryanarayanan A, Liang J, Meyer EM, Lindemeyer AK, Chandra D, Homanics GE, Sieghart W, Olsen RW, Spigelman I (2011) Subunit compensation and plasticity of synaptic GABA(A) receptors induced by ethanol in $\alpha 4$ subunit knockout mice. Front Neurosci 5:110. CrossRef Medline 
Tretter V, Hauer B, Nusser Z, Mihalek RM, Höger H, Homanics GE, Somogyi P, Sieghart W (2001) Targeted disruption of the GABA(A) receptor $\delta$ subunit gene leads to an up-regulation of $\gamma 2$ subunit-containing receptors in cerebellar granule cells. J Biol Chem 276:10532-10538. CrossRef Medline

Tretter V, Revilla-Sanchez R, Houston C, Terunuma M, Havekes R, Florian C, Jurd R, Vithlani M, Michels G, Couve A, Sieghart W, Brandon N, Abel
T, Smart TG, Moss SJ (2009) Deficits in spatial memory correlate with modified $\gamma$-aminobutyric acid type A receptor tyrosine phosphorylation in the hippocampus. Proc Natl Acad Sci U S A 106:20039-20044. CrossRef Medline

Whitten MK (1957) Effect of exteroceptive factors on the oestrous cycle of mice. Nature 180:1436. CrossRef Medline 